\title{
With or Without EU? The Common Travel Area After Brexit - ERRATUM
}

\author{
Sylvia de Mars and C. R. G Murray
}

https://doi.org/10.1017/glj.2020.46 Published by Cambridge University Press, 28 August 2020

Keywords: Brexit; Common Travel Area; Freedom of movement; UK-EU Withdrawal Agreement; Erratum

During the editing process, an error was introduced that resulted in a reference to the wrong case number in footnote 82 (Case C-202/13) on page 823.

The correct details are:

82. The Immigration (European Economic Area) Regulations 2016, reg. 2(1) (SI 2016/1052) (UK) ("In these Regulations: 'EEA national' means a national of an EEA State who is not also a British citizen."). This exception was introduced into the EEA Regulations after the CJEU's McCarthy decision. McCarthy, Case C-434/09.

\section{Reference}

De Mars, S., \& Murray, C. (2020). With or Without EU? The Common Travel Area After Brexit. German Law Journal, 21(5), 815-837. doi: $10.1017 /$ glj.2020.46

Cite this article: de Mars S, Murray CRG (2021). With or Without EU? The Common Travel Area After Brexit - ERRATUM. German Law Journal 22, 914. https://doi.org/10.1017/glj.2021.30

(c) The Author(s), 2021. Published by Cambridge University Press on behalf of the German Law Journal. This is an Open Access article, distributed under the terms of the Creative Commons Attribution-NonCommercial-ShareAlike licence (http://creativecommons.org/ licenses/by-nc-sa/4.0/), which permits non-commercial re-use, distribution, and reproduction in any medium, provided the same Creative Commons licence is included and the original work is properly cited. The written permission of Cambridge University Press must be obtained for commercial re-use. 